\title{
The detrimental effects of recruitment maneuvers on mucus clearance in an animal model of primary ards
}

\author{
G Li Bassi ${ }^{1 *}$, C Chiurazzi ${ }^{2}$ E Aguilera Xiol ${ }^{1}$, D Marti ${ }^{1}$, C Talitho ${ }^{3}$, R Amaro ${ }^{1}$, C Travierso ${ }^{2}$, M Carbonara², M Rigol ${ }^{1}$, \\ O Comino-Trinidad ${ }^{4}$, A Torres $^{1}$
}

From ESICM LIVES 2015

Berlin, Germany. 3-7 October 2015

\section{Introduction}

The recruitment maneuver (RM) is a transient increase in trans-pulmonary pressure to reopen collapsed alveoli. During mechanical ventilation, mucus could be displaced toward the lungs, driven by the inspiratory flow, via a two-phase gas-liquid flow mechanism [1].

\section{Objectives}

We evaluated, in an animal model of primary acute respiratory distress syndrome (ARDS), the effects of different RMs on the displacement of respiratory secretions, gas exchanges, and respiratory system elastance (Ers).

\section{Methods}

Seven pigs $(34 \pm 1.8 \mathrm{Kg})$ were intubated and mechanically ventilated. Animals were challenged into the lungs with P.aeruginosa to develop ARDS. After 48 hours from bacterial inoculation, we applied, in a randomized sequence, four different RMs: 1) extended sigh, in volume control (VC) mode, through stepwise increments of $5 \mathrm{cmH}_{2} \mathrm{O}$ of positive end expiratory pressure (PEEP), every $30 \mathrm{sec}$, up to $40 \mathrm{~cm} \mathrm{H}_{2} 0 ; 2$ ) maximal recruitment strategy, in pressure-control (PC) mode, starting with PEEP of 25 and driving pressure of $15 \mathrm{cmH}_{2} \mathrm{O}$, then sequential increments of $5 \mathrm{cmH}_{2} \mathrm{O}$ of PEEP, every min, up to $35 \mathrm{cmH}_{2} 0 ; 3$ ) sustained inflation, through continuous positive airway pressure held at $40 \mathrm{~cm} \mathrm{H}_{2} \mathrm{O}$ for $30 \mathrm{sec}$; 4) sudden increase in driving pressure and PEEP in PC-mode, through an increase of PEEP to 16 and driving pressure to $24 \mathrm{cmH}_{2} \mathrm{O}$ for

${ }^{1}$ Hospital Clinic de Barcelona, Pulmonary and Critical Care Medicine, Barcelona, Spain

Full list of author information is available at the end of the article
90 sec. A 1-hour washout period was allowed between interventions. At baseline, and throughout each RM, mucus transport was assessed through fluoroscopic tracking of radiopaque disks, insufflated into the airways. Mucus clearance velocity (MCV) was computed. Positive and negative MCV values describe mucus moving toward the glottis and lungs, respectively. After 15 min from completion of each RM, arterial partial pressures of oxygen/inspiratory fraction of oxygen and carbon dioxide $\left(\mathrm{Pa} 02 / \mathrm{F}_{\mathrm{I}} 02\right.$ and $\left.\mathrm{PaC02}\right)$, and Ers were assessed and adjusted per baseline values.

\section{Results}

At baseline, animals were ventilated with respiratory rate of $40 \pm 10 \mathrm{breaths} / \mathrm{min}$, tidal volume $260 \pm 14 \mathrm{~mL}$, and PEEP $8.5 \pm 0.5 \mathrm{~cm} \mathrm{H}_{2} \mathrm{O}$. As a result, $\mathrm{Pa} 02 / \mathrm{F}_{\mathrm{I}} \mathrm{O} 2$ and $\mathrm{PaC} 02$ were $277 \pm 100$ and $51 \pm 13 \mathrm{mmHg}$, respectively. The effects of RMs on MCV, Ers, $\mathrm{Pa} 02 / \mathrm{F}_{\mathrm{I}} 02$ and $\mathrm{PaC} 02$ are reported in table $1 . \mathrm{MCV}$, during RMs that either improved or impaired $\mathrm{Pa} 02 / \mathrm{F}_{\mathrm{I}} 02$, was $0.0 \pm 0.5$ and $-0.2 \pm 1.0 \mathrm{~mm} / \mathrm{min}$, respectively $(\mathrm{p}=0.591)$.

\section{Conclusions}

In a model of primary ARDS, we found that different methods to recruit the lungs produce similar results on gas exchanges and Ers, but consistently impair mucus clearance. Likely, the distinctive inspiratory airflow patterns generated by RMs are major culprit in these findings.

\section{Grant Acknowledgment}

2013 ESICM/ECCRN young investigator award. 
Table 1

\begin{tabular}{|c|c|c|c|c|c|c|}
\hline & Baseline & $\begin{array}{l}\text { Extended } \\
\text { sigh }\end{array}$ & $\begin{array}{l}\text { Maximal } \\
\text { recruitment } \\
\text { strategy }\end{array}$ & $\begin{array}{l}\text { Sustained } \\
\text { inflation }\end{array}$ & $\begin{array}{l}\text { Sudden increase driving } \\
\text { pressure and PEEP }\end{array}$ & P-value \\
\hline Mucus Clearance (mm/min) & $2.2 \pm 2.4$ & $0.3 \pm 0.9$ & $-0.2 \pm 0.9$ & $-0.3 \pm 0.6$ & $-0.1 \pm 0.7$ & 0.021 \\
\hline Incidence of mucus moving toward lungs (\%) & 0 & 50.0 & 57.1 & 80.0 & 57.1 & 0.013 \\
\hline $\begin{array}{l}\text { Respiratory System Elastance After-Before } \\
\text { recruitment maneuver (cm H2O/L) }\end{array}$ & NA & $-5.8 \pm 3.5$ & $-9.0 \pm 8.9$ & $-4.1 \pm 3.1$ & $-3.6 \pm 3.9$ & 0.124 \\
\hline $\begin{array}{l}\text { Pa02/F102 After-Before recruitment maneuver } \\
(\mathrm{mmHg})\end{array}$ & NA & $4.1 \pm 63.1$ & $2.8 \pm 45.8$ & $13.6 \pm 42.3$ & $-2.2 \pm 41.6$ & 0.937 \\
\hline $\begin{array}{l}\text { PaC02 After-Before recruitment maneuver } \\
(\mathrm{mmHg})\end{array}$ & NA & $6.9 \pm 7.8$ & $3.9 \pm 7.4$ & $6.7 \pm 13.6$ & $1.8 \pm 4.0$ & 0.616 \\
\hline
\end{tabular}

[Effects of recruitment maneuvers]

\section{Authors' details}

'Hospital Clinic de Barcelona, Pulmonary and Critical Care Medicine,

Barcelona, Spain. ${ }^{2}$ University of Milano. Fondazione IRCCS Ca' Granda

Ospedale Maggiore Policlinico, Milan, Italy. ${ }^{3}$ Pontifícia Universidade Catolica,

CNPq fellow (2012-2014), Rio Grande do Sul, Brazil. "University of Barcelona,

Barcelona, Spain.

Published: 1 October 2015

\section{Reference}

1. Li Bassi G: Crit Care Med 2012, 40:895-902.

doi:10.1186/2197-425X-3-S1-A308

Cite this article as: $L i$ Bassi et al:: The detrimental effects of recruitment maneuvers on mucus clearance in an animal model of primary ards.

Intensive Care Medicine Experimental 2015 3(Suppl 1):A308.

\section{Submit your manuscript to a SpringerOpen ${ }^{\circ}$ journal and benefit from:}

- Convenient online submission

- Rigorous peer review

- Immediate publication on acceptance

- Open access: articles freely available online

- High visibility within the field

- Retaining the copyright to your article

Submit your next manuscript at $>$ springeropen.com 